\title{
Penentuan Lokasi TPA dengan Pendekatan Spasial di Pulau Kecil Kota Makassar
}

\section{Determining the Location of Landfill with Spatial Approach in Small Island of Makassar City}

\author{
Agus Bintara Birawida ${ }^{1 *}$, Bukroanah Amir Makkau ${ }^{1}$, Indra Dwinata ${ }^{2}$ \\ ${ }^{1}$ Departemen Kesehatan Lingkungan Fakultas Kesehatan Masyarakat Universitas Hasanuddin \\ ${ }^{2}$ Departemen Epidemiologi Fakultas Kesehatan Masyarakat Universitas Hasanuddin \\ ("agusbirawida@gmail.com)
}

\begin{abstract}
ABSTRAK
Sampah merupakan permasalahan lingkungan yang sampai saat ini masih terjadi di daerah kepulauan, khususnya pulau-pulau kecil. Setiap tahun sampah yang dibuang ke laut terus mengalami peningkatan yang diakibatkan oleh aktivitas masyarakat sekitar pulau. Tujuan penelitian untuk menentukan titik koordinat terbaik dalam penempatan lokasi Tempat Pembuangan Akhir Sampah (TPA). Penelitian menggunakan metode deskriptif dengan pendekatan spasial. Pengambilan data untuk penentuan titk terbaik dalam penempatan lokasi TPA didasarkan pada pengambilan titik koordinat GPS dan pengukuran di lapangan. Hasil penelitian menunjukkan bahwa berdasarkan pengambilan titik koordinat GPS dan pertimbangan kategori pengukuran objektif, yaitu kemiringan lereng, jarak terhadap garis pantai dan pemukiman, kapasitas lahan, kedalam muka air tanah, serta kapasitas lahan didapatkan hasil Lokasi TPA terbaik untuk Pulau Kodingareng Lompo berada pada pada titik koordinat lintang 119,26514 ${ }^{\circ}$ dan bujur $-5,14793^{\circ}$ yang letaknya berada di tengah pulau. Untuk pembuatan TPA sampah, sanitary landfill merupakan jenis TPA yang paling cocok diterapkan di Pulau Kodingareng Lompo.
\end{abstract}

Kata kunci : Sampah, TPA, spasial

\section{ABSTRACT}

Solid waste is an environmental issue that currently still occurs in the islands, especially for small islands. Every year waste disposed into the sea continues to experience levels caused by community activities around the island. The aimof the research is to determine the best point in the location of the Final Waste Disposal Site (TPA). This research uses descriptive method with spatial approach. Retrieval of data to determine locations in GPS location and measurement in the field. The results showed that the GPS coordinate points and the objectives of the measurement purposes, namely the slope of the slope, the distance between the coast and land, the land function, including the air of the ground, and the capacity of the available land for locations on Kodingareng Lompo Island latitude $119.26514^{\circ}$ and longitude of $-5.14793^{\circ}$ placed in the center of the island. Sanitary landfill is the most suitable type of landfill to be applied on Kodingareng Lompo Island.

Keywords : Solid waste, landfill, spatial 


\section{PENDAHULUAN}

Kesehatan masyarakat merupakan serangkaian upaya untuk menyehatkan seluruh penduduk tanpa membedakan faktor umur, ras, agama, jenis kelamin maupun tempat tinggal. Dalam satu wilayah RT atau RW bahkan suatu negara, semua memiliki kesamaan hak untuk mendapat perlindungan terhadap ancaman bahaya kesehatan dan peningkatan derajat kesehatan secara adil dan merata. ${ }^{1}$ Salah satu ciri kesehatan masyarakat yaitu upaya menyehatkan penduduk dengan berorientasi pada pencegahan melalui lingkungan pemukiman. ${ }^{2}$ Salah satu permasalah lingkungan di pulau kecil yaitu sampah yang tidak diolah dan langsung dibuang ke lingkungan. ${ }^{3}$

Penumpukan sampah yang tidak dikelola dengan baik dapat memicu penyebaran penyakit, selain bau tidak sedap yang mengganggu pernapasan. ${ }^{4}$ Penyakit diare salah satunya diakibatkan oleh pajanan sampah padat misalnya melalui pengambilan sampah atau akumulasi sampah dilingkungan. ${ }^{5}$ Menurut data World Health Organization (WHO) pada tahun 2008, terdapat $15 \%$ dari kematian anak di bawah 5 tahun disebabkan oleh penyakit diare. ${ }^{6}$ Hasil penelitian berdasarkan analisis menunjukkan nilai $\mathrm{OR}=3,3$ dan $95 \% \mathrm{CI}=1,2-9,4$ artinya pengelolaan sampah merupakan faktor risiko terjadinya diare balita. Responden dengan pengelolaan sampah yang buruk mempunyai risiko 3,3 kali mengalami kejadian diare balita dibandingkan responden dengan pengelolaan sampah yang baik. ${ }^{7}$ Berdasarkan data Badan Pusat Statistik Kota Makassar tahun 2014, Pulau Kodingareng Lompo masuk ke dalam peringkat 5 terbesar pulau dengan penyakit diare tertinggi, yaitu sebesar 98 penderita pada tahun 2012. Pada tahun 2013 penderita diare meningkat menjadi 387 kasus, tahun 2014 meningkat menjadi 431 kasus dan sampai akhir tahun 2015 meningkat menjadi 478 kasus. ${ }^{8}$ Hal ini berarti tiap tahunnya terjadi peningkatan kasus diare di Pulau Kodingareng Lompo.

Permasalahan yang ada di pulau kecil adalah tidak ada tempat pembuangan sampah dan jauhnya jarak pulau kecil ke kota yang memiliki Tempat Pembuangan Akhir (TPA), sedangkan produksi sampah di pulau setiap harinya semakin meningkat yang mengakibatkan sampah yang dihasilkan dibuang di laut, lahan kosong atau de- ngan cara lain dibakar yang dapat menimbulkan penyakit. Untuk itu perlu adanya penentuan lokasi TPA sampah di Pulau Kodingareng Lompo. Guna memenuhi kebutuhan ruang dalam menetapkan lokasi TPA seringkali dijumpai masalah-masalah besar yang perlu ditangani dengan seksama, seperti ketersediaan lahan, konflik kepentingan dan penurunan mutu lingkungan. ${ }^{9}$ SIG merupakan salah satu program pemetaan yang sudah banyak digunakan dan diaplikasikan untuk analisis penentuan lokasi TPA sampah. ${ }^{10}$

SIG digunakan untuk mengevaluasi setiap kriteria penilaian secara spasial melalui tiga tahap, yaitu tahap penilaian pertama dengan menggunakan metode binary untuk menentukan zona layak dan tidak layak, penilaian tahap kedua menentukan kesesuaian lahan berdasarkan kriteria penyisih dan penilaian ketiga dengan metode overlay untuk menetapkan lokasi terbaik. ${ }^{10}$ Penelitian yang dilakukan oleh Setiawan, mengatakan bahwa dengan bantuan SIG dapat ditentukan lokasi atau lahan untuk rekomendasi TPA sampah. ${ }^{11} \mathrm{Ke}-$ layakan lahan dihasilkan dari overlay peta bentuk lahan dan peta penutup lahan, sehingga diperoleh lokasi yang layak berdasarkan bentuk lahan dan layak berdasarkan penutup lahan menggunakan SIG. Dengan memanfaatkan SIG dapat ditentukan lokasi rekomendasi Tempat Pembuangan Akhir (TPA) sampah. Penggunaan SIG akan mempersingkat waktu analisis berbagai parameter penilaian kesesuaian lahan untuk lokasi TPA secara umum maupun secara detail dengan tingkat akurasi data yang tinggi. ${ }^{12}$

TPA sampah dibutuhkan di Pulau Kodingareng Lompo, melihat banyaknya sampah yang berserakan di sepanjang pulau yang berasal dari sampah masyarakat pulau itu sendiri. Untuk itu, penelitian ini bertujuan mengetahui gambaran kepemilikan dan jenis tempat sampah rumah tangga, pengelolaan sampah rumah tangga, kondisi sampah di lingkungan rumah warga, potensi gangguan kesehatan akibat sampah, serta penentuan nilai kelayakan lokasi TPA sampah melalui analisis spasial, tahap pertama berupa kemiringan lereng, jarak terhadap garis pantai, jarak terhadap pemukiman, luas lahan untuk operasional dan kedalaman muka air tanah. 


\section{BAHAN DAN METODE}

Jenis penelitian ini menggunakan metode deskriptif dengan pendekatan berbasis pemetaan spasial. Penelitian ini dilaksanakan di Pulau Kodingareng Lompo yang berada di wilayah administratif Kota Makassar Kecamatan Ujung Tanah Kelurahan Kodingareng pada bulan Januari Februari 2016. Metode deskriptif dilakukan dengan menggambarkan informasi terkait kategori obyektif dalam penentuan untuk penempatan lokasi TPA sampah dengan mewawancari sebanyak 89 KK yang berada di Pulau Kodingareng Lompo. Banyak responden ditentukan menggunakan lameshow dengan menggunakan teknik purposive sampling.

Pengumpulan data dilakukan dengan wawancara langsung dengan salah satu anggota Kepala Keluarga menggunakan kuesioner mengenai pembuangan sampah, penyakit akibat sampah dan TPA sampah. Pengambilan titik koordinat menggunakan GPS untuk mengukur kemiringan le-reng dan letak wilayah pengukuran, pengukuran kedalaman muka air tanah menggunakan meteran dan pengambilan data sekunder mengenai kondisi geografis dan kependudukan di Kantor Kelurahan Kodingareng. Analisis data yang digunakan, yaitu univariat. Data yang diperoleh diolah secara komputerisasi dengan menggunakan program analisi melalui tahapan editing, coding, entry data dan analisis data. Selanjutnya data disajikan dalam bentuk tabel, peta dan narasi.

\section{HASIL}

Parameter penentuan lokasi TPA sampah di Pulau Kodingareng Lompo tahap pertama, yaitu kemiringan lereng dengan nilai $<20 \%$ layak dan $>20 \%$ tidak layak, jarak terhadap pemukiman $>50$ meter layak dan $<50$ meter tidak layak. Jarak terhadap garis pantai $>20$ meter layak dan $<20$ meter tidak layak (Tabel 1). Parameter penentuan lokasi

Tabel 1. Kriteria Objektif Kelayakan Pulau Kecil untuk Penentuan Lokasi TPA Sampah

\begin{tabular}{cclc}
\hline No & \multicolumn{1}{c}{ Parameter } & Indikator & Nilai \\
\hline 1 & Kemiringan lereng & $<20 \%$ & 1 \\
& & $>20 \%$ & 0 \\
2 & Jarak terhadap garis pantai & $>50$ meter & 1 \\
& & $<50$ meter & 0 \\
3 & \multirow{2}{*}{ Jarak terhadap pemukiman } & $>20$ meter & 1 \\
& & $<20$ meter & 0 \\
\hline
\end{tabular}

Sumber : MENPU Nomor 125 Tahun 1991 dengan penyesuaian

Tabel 2. Kriteria Objektif Kelayakan Penyisih untuk Penentuan Lokasi TPA Sampah

\begin{tabular}{cllcc}
\hline No & \multicolumn{1}{c}{ Parameter } & \multicolumn{1}{c}{ Indikator } & Bobot & Nilai \\
\hline 1. & Kapasitas Lahan & $>10$ tahun & 10 & 4 \\
& & $5-10$ tahun & 8 & 3 \\
& $3-5$ tahun & 5 & 2 \\
2. Kedalaman muka air tanah & $>3$ tahun & 1 & 1 \\
& & $1-2$ meter & 10 & 3 \\
& $<1$ meter & 5 & 2 \\
& & 1 & 1 \\
\hline
\end{tabular}

Sumber : MENPU Nomor 125 Tahun 1991 dengan penyesuaian

Tabel 3. Perkiraan Luas Lahan yang Dibutuhkan Berdasarkan Kriteria Penyisih Lokasi TPA Sampah

\begin{tabular}{ccc}
\hline Kapasitas Lahan (tahun) & Luas $\left(\mathbf{m}^{\mathbf{2}} / \mathbf{t a h u n}\right)$ & Total Luas $\left(\mathbf{m}^{\mathbf{2}}\right)$ \\
\hline 3 tahun & 68 & 204 \\
5 tahun & 68 & 340 \\
10 tahun & 68 & 680 \\
\hline
\end{tabular}

Sumber: Data Primer, 2016 Perhitungan Perkiraan Luas Lahan TPA Sampah 
TPA sampah di Pulau Kodingareng Lompo tahap kedua kelayakan penyisih untuk nilai kesesuaian, yaitu kapasitas lahan untuk operasional dan kedalaman muka air tanah (Tabel 2).

Analisis spasial kelayakan Pulau Kodingareng tahap pertama dengan metode boolean, yaitu kemiringan lereng $<20 \%$, jarak terhadap garis pantai $>50$ meter dan jarak terhadap pemukiman $>20$ meter. Analisis tahap kedua, yaitu kelayakan penyisih untuk penentuan nilai kesesuaian, yaitu luas lahan untuk operasional, yaitu 0,56 hektar. Perkiraan luas lahan TPA sampah untuk penggunaan 3 tahun, yaitu sebesar $204 \mathrm{~m}^{2}$. Untuk penggunaan 5 tahun, yaitu sebesar $340 \mathrm{~m}^{2}$ dan untuk penggunaan 10 tahun, yaitu sebesar $680 \mathrm{~m}^{2}$ (Tabel $3)$.
Pengukuran kedalaman muka air tanah sebanyak 14 lokasi di Pulau Kodingareng Lompo. Adapun kedalaman muka air tanah tertinggi di Pulau Kodingareng Lompo berada pada stasiun 5, yaitu sebesar $1 \mathrm{~m} 50 \mathrm{~cm}$ atau $150 \mathrm{~cm}$ dan kedalaman terendah berada pada stasiun 3,10 , dan 12 , yaitu masing-masing sebesar $1 \mathrm{~m} 10 \mathrm{~cm}$ atau 110 $\mathrm{cm}$. Adapun secara keseluruhan kedalaman muka air tanah di Pulau Kodingareng Lompo berada dibawah dua meter $(<2$ meter). Nilai kesesuaian lahan untuk kriteria kelayakan penyisih penentuan lokasi TPA sampah di Pulau Kodingareng Lompo, yaitu 50 (Gambar 1). Daerah lokasi TPA sampah di Pulau Kodingareng Lompo yang berada pada titik koordinat lintang $119,26514^{\circ}$ dan bujur $-5,14793^{\circ}$ dengan ketinggian 5 meter. Lokasi tersebut berada

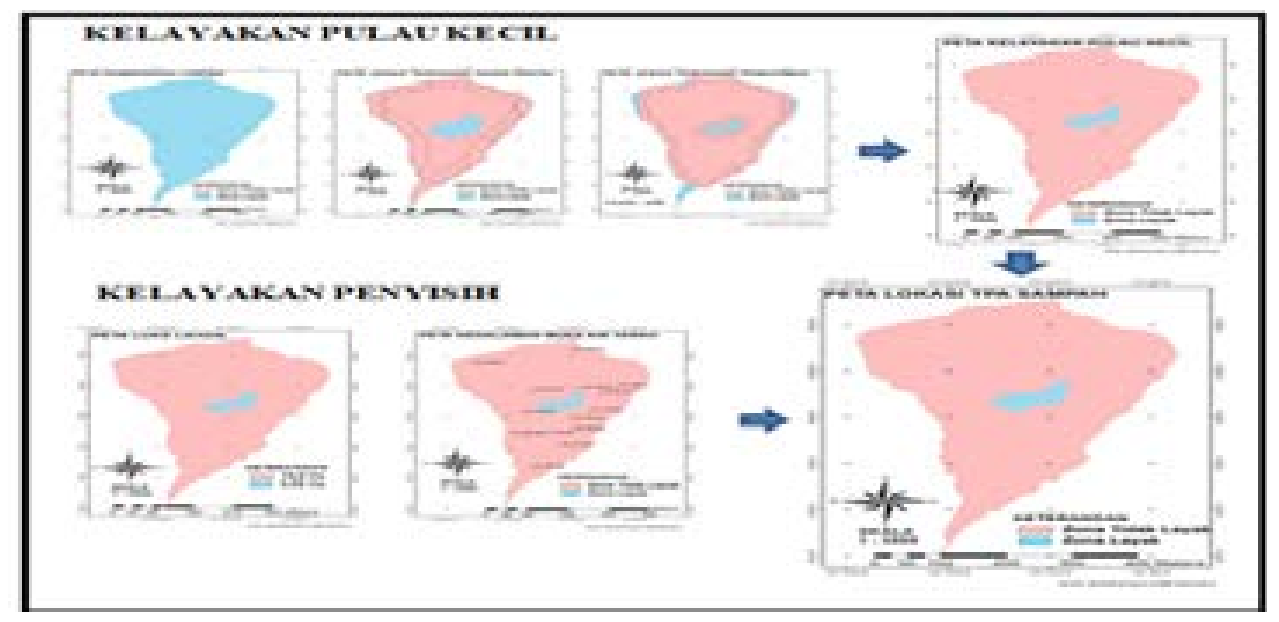

Gambar 1. Peta Kelayakan Lokasi TPA Sampah Pulau Kodingareng Lompo

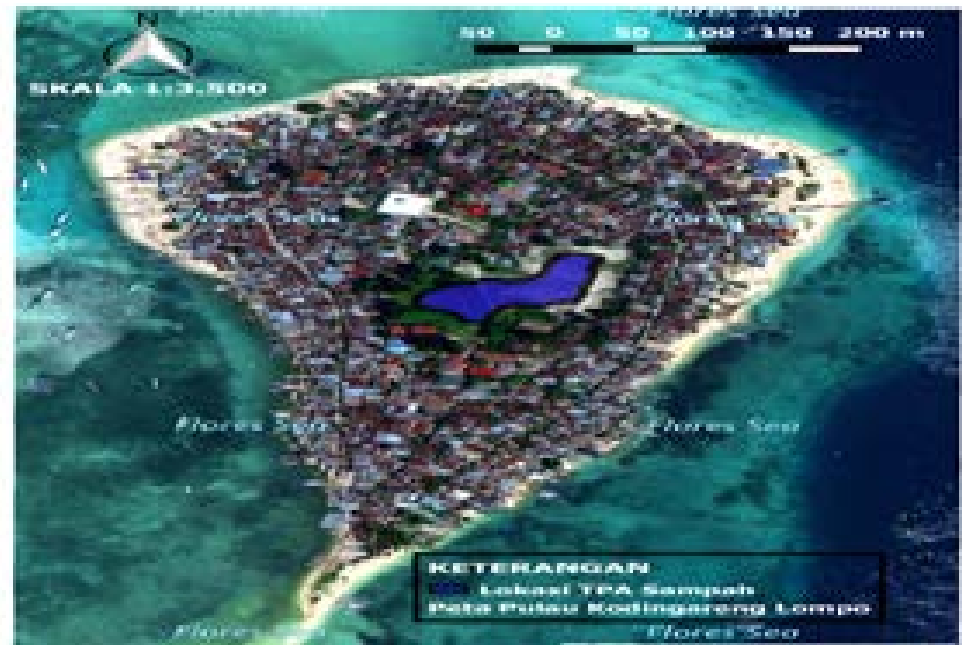

Gambar 2. Peta Lokasi TPA Sampah Pulau Kodingareng Lompo 
pada kemiringan lereng 3-8\% dengan luas lahan, yaitu $0,56 \mathrm{Ha}$ atau $5600 \mathrm{~m}^{2}$ yang dapat menampung sampah sampah dengan 19 tahun dengan ketinggian timbunan 7 meter (Gambar 2).

\section{PEMBAHASAN}

Setiap rumah tangga tentunya akan menghasilkan sampah rumah tangga setiap harinya. Jumlah anggota keluarga mempengaruhi jumlah timbulan sampah yang dihasilkan tiap rumah tangga. Hasil penelitian menunjukkan semua responden memiliki tempat sampah di rumah dengan jenis tempat sampah, yaitu semi permanen. Jenis tempat sampah rumah tangga di Pulau Kodingareng Lompo berdasarkan observasi peneliti terbuat dari plastik. Berdasarkan Peraturan Menteri Dalam Negeri Nomor 33 Tahun 2010 tentang Pedoman Pengelolaan Sampah, tempat sampah rumah tangga adalah wadah penampungan sampah yang berupa bak/bin/tong/kantong/keranjang sampah.

Jenis sampah rumah tangga yang dihasilkan ada dua berdasarkan zat kimia yang terkandung didalamnya, yaitu sampah organik dan anorganik. ${ }^{13}$ Data penelitian menunjukkan bahwa $51,7 \%$ mengatakan bahwa sampah yang sering dihasilkan, yaitu sampah anorganik dan 48,3\% mengatakan bahwa sampah yang sering dihasilkan, yaitu sampah organik. Berdasarkan hasil tinjauan lapangan, sampah anorganik yang dihasilkan penduduk kebanyakan berasal dari sampah plastik atau plastik bungkusan makanan anak-anak dan hasil observasi menunjukkan kondisi sampah di lingkungan rumah dengan banyak sampah berserakan dan bertumpuk 49,4\%.

Sampah jika dibuang secara sembarang akan mencemari lingkungan, bahkan walaupun sampah tersebut di buang di tempat yang telah disediakan yaitu tempat sampah, juga masih tetap merupakan suatu masalah. Sampah dianggap sebagai suatu masalah yang sangat mengganggu dengan berbagai dampak yang ditimbulkan antara lain yaitu terhadap kesehatan maupun estetika dan keindahan. ${ }^{14}$ Untuk itu, perlu dilakukan pengelolaan sampah rumah tangga. Pengelolaan sampah yang baik, yaitu dengan memisahkan tempat sampah organik dan anorganik. Berdasarkan hasil penelitian di Pulau Kodingareng Lompo, tidak ada satu pun responden yang melakukan pemilahan sampah rumah tangga. Sampah rumah tangga yang dihasilkan dikumpulkan di tempat sampah kemudian $98,9 \%$ membuang sampah tersebut ke laut.

Sampah merupakan masalah lingkungan dan masalah kesehatan masyarakat untuk itu perlu adanya pengolahan sampah. Salah satu cara pengelolaan sampah, yaitu dengan membuat TPA sampah. Di Kota Makassar, masyarakat mempunyai TPA Tamangapa sebagai tempat pembuangan akhir sampah. Berbeda hal-nya dengan pulau kecil, walaupun Pulau Kodingareng Lompo merupakan wilayah Kota Makassar, tetapi sampah yang mereka hasilkan tidak dapat dibuang di TPA Tamangapa karena jarak TPA Tamangapa ke Pulau Kodingareng Lompo di batasi dengan laut. Akibatnya warga membuang sampah rumah tangga mereka di pinggir pantai atau di laut. Berdasarkan hasil penelitian, $100 \%$ setuju jika TPA sampah dapat dibuat di Pulau Kodingareng Lompo. Namun, yang menjadi masalah adalah pulau kecil seperti Pulau Kodingareng Lompo memiliki luas wilayah yang kecil. Sehingga untuk membuat TPA sampah di pulau kecil tidak dapat mengikuti nilai ukur kelayakan berdasarkan Standar Nasional Indonesia yang telah ada karena standar tersebut untuk kawasan regional atau perkotaan.

Pengukuran kelayakan TPA sampah dibagi atas dua, yaitu kelayakan pulau kecil dan kelayakan penyisih. Kelayakan pulau kecil yang diukur, yaitu kemiringan lereng, jarak terhadap garis pantai dan jarak terhadap pemukiman, lokasi TPA sampah yang dapat dibuat berdasarkan kriteria kelayakan pulau kecil di Pulau Kodingareng Lompo berada 20 meter dari jarak pemukiman ke tanah kosong. Kriteria kelayakan pulau kecil ini diukur dengan menggunakan metode boolean, yaitu memberikan angka 0 untuk daerah yang tidak layak dan angka 1 untuk daerah yang layak. Hal ini sejalan dengan penelitian yang dilakukan oleh Irawan dan Andi, yaitu kemiringan lereng berkaitan erat dengan kemudahan pekerjaan konstruksi dan operasional TPA Sampah. Semakin terjal suatu daerah maka akan semakin sulit dalam kegiatan/pekerjaan konstruksinya dan pengoperasiannya. Sebagian besar wilayah studi termasuk sesuai karena kemiringan lerengnya relatif datar. ${ }^{15}$

Kelayakan penyisih yang diukur, yaitu luas lahan untuk operasional dan kedalaman muka air tanah. Dalam mengetahui nilai kelayakan penyisih 
ini digunakan metode Weighted Linear Combination (WLC), metode ini digunakan untuk operasi perhitungan nilai kesesuaian sebagai lokasi TPA sampah dan membagi tingkat kesesuaian lahan yang terdiri dari 5 tingkat yaitu sangat rendah dengan nilai antara 30-41, rendah dengan nilai antara 42-53, sedang dengan nilai antara 54-65, tinggi dengan nilai antara 66-77 dan sangat tinggi dengan nilai antara 78-90. Oleh karena tanah kosong sebagai zona layak lokasi TPA sampah di Pulau Kodingareng Lompo, maka luas lahan tersebut yaitu $5.600 \mathrm{~m}^{2}$, maka lokasi tersebut dapat menampung sampah selama \pm 82 tahun jika disertai dengan pengomposan dan daur ulang sampah plastik. Sehingga nilai kesesuaian lahan, yaitu 40 .

Berdasarkan penelitian yang dilakukan oleh Darnas, yang melakukan penelitian mengenai Studi Kelayakan Lokasi Tempat Pemrosesan Akhir (TPA) sampah Kabupaten Padang Pariaman, secara garis besar di atas kebutuhan lahan TPA untuk 20 tahun yang akan datang adalah $11 \mathrm{Ha}$, ketinggian pengurugan pada perhitungan diatas hanya 15 meter dan seluruh sampah ditimbun pada lahan urug tanpa ada yang diolah melalui proses recycler (daur ulang) serta data timbulan sampah serta faktor pemadatan sampah. ${ }^{16}$

Untuk parameter kedalaman muka air tanah nilai kesesuaian lahan untuk TPA sampah di Pulau Kodingareng Lompo terhadap kedalaman muka air tanah yaitu 10. Sehingga untuk kelayakan penyisih dengan parameter luas lahan untuk operasional dan kedalaman muka air tanah, nilai kesesuaian lahan TPA sampah, yaitu 50 dengan kategori rendah untuk penggunana lokasi TPA sampah. Lokasi TPA sampah di Pulau Kodingareng Lompo berdasarkan kelayakan pulau kecil dan kelayakn penyisih berada pada titik koordinat lintang $119,26514^{\circ}$ dan bujur $-5,14793^{\circ}$ dengan ketinggian 5 meter serta kedalaman muka air tanah $<2$ meter.

Sampah yang berada di TPA sampah tentunya akan menimbulkan beberapa masalah seperti menimbulkan bau yang tidak sedap. Berdasarkan hasil peneliti, $34,8 \%$ tidak setuju jika TPA sampah dibangun di sekitar rumah mereka karena alasan bau yang dihasilkan oleh sampah yang ada di TPA sampah nantinya, tetapi $65,2 \%$ setuju saja jika TPA sampah nantinya akan dibangun di sekitar rumah responden tersebut, jika memang terdapat lokasi yang layak untuk pembuatan TPA sampah.
Syarat pembuatan TPA sampah di Pulau Kodingareng Lompo, yaitu menggunakan sistem pengelolaan sampah sanitary landfill sederhana. Sistem pembuangan akhir sampah yang dilakukan dengan cara sampah ditimbun dan dipadatkan, kemudian ditutup dengan tanah sebagai lapisan penutup. Selain itu, syarat pembuatan TPA sampah, yaitu dengan manajemena pengelolaan sampah yang baik. Manajemen pengelolaan sampah yang dimaksud, yaitu pengelolaan dari sumber penghasil sampah ke bak sampah dengan pemilahan sampah organik dan anorganik kemudian pengumpulan dan pengangkutan sampah dari bak sampah ke TPA sampah. Sampah yang dibuang ke bak sampah dapat diolah terlebih dahulu sebelum di buang ke TPA, untuk sampah organik dapat dijadikan kompos dan sampah plastik dapat di daur ulang. Penyimpanan sampah di bak sampah tidak boleh lama, paling lama 2-3 hari dan sebaiknya memiliki penutup untuk menghindari sampah berceceran yang dapat mengundang lalat dan tikus. ${ }^{17}$

Pulau Kodingareng Lompo berdasarkan kriteria pulau kecil dan kriteria penyisih dapat dibuatkan TPA sampah, tetapi dengan tingkat kesesuaian lahan yang rendah. Untuk itu, sebaiknya di Pulau Kodingareng Lompo dilestarikan 3M (Mengurangi, Mendaur ulang dan Menggunakan kembali) untuk mengurangi timbulan sampah tiap harinya. Namun, untuk mengurangi masalah sampah tersebut, perlu adanya dukungan dari pemerintah sebagai pemegang dan penentu kebijakan dengan memberikan saran dan prasarana seperti terciptanya program bank sampah dan pelatihan daur ulang bagi masyarakat.

\section{KESIMPULAN DAN SARAN}

Penelitian ini menyimpulkan bahwa sebanyak semua rumah tangga di Pulau Kodingareng Lompo memiliki tempat sampah semi permanen sebagai Tempat Pembuangan Akhir namun hampir semua masyarakat di pulau membuang sampah di laut tanpa melakukan pengolahan. Untuk penentuan lokasi terbaik penempatan TPA berada pada titik koordinat lintang $119,26514^{\circ}$ dan bujur $-5,14793^{\circ}$ yang tepatnya berada di pertengahan pulau dengan ketinggian 5 meter serta kedalaman muka air tanah $<2$ meter.

Saran terhadap pihak Pemerintah Kota Makassar agar mengupayakan pembuatan TPA di 
Pulau Kodingareng Lompo maupun pulau kecil dengan syarat menggunakan sistem sanitary landfill sederhana dan manajemen pengelolaan sampah yang baik mulai dari sumber sampah sampai ke TPA. Untuk penelitian selanjutnya, diharapkan dapat mengukur parameter kelayakan TPA sampah lainnya untuk mencegah dampak negatif dari TPA tersebut.

\section{DAFTAR PUSTAKA}

1. U, F, Achmadi. Kesehatan Masyarakat Teori dan Aplikasi. Jakarta: Rajafindo Persada; 2013.

2. U, F, Achmadi. Dasar-Dasar Penyakit Berbasis Lingkungan. Jakarta: Rajafindo Persada; 2011.

3. Nganro, Noorsalam R. dan Gede Suantika. Urgensi Ecosystem Approach dalam Pengelolaan Pesisir dan Pulau-Pulau Kecil di Indonesia. Bandung: ITB; 2009.

4. Firmiana, Masni Erika. Go Green Pelatihan untuk Mendorong Perilaku Konservasi dan Pro Lingkungan bagi Santri Al Ghazali Kota Bogor. Jurnal Al-Azhar Indonesia Seri Humaniora. 2012; 1(3).

5. Nia, Ananda. Suharto dan Sitanggang, Polisman. Gambaran Sumber Air Minum, Tempat Pembuangan Tinja dan Tempat Pembuangan Sampah dan Penyakit Diare pada Balita di Wilayah Kerja Puskesmas Koni Kota Jambi Tahun 2013 [Skripsi]. Jambi: Fakultas Kedokteran dan Ilmu Kesehatan Universitas Jambi; 2013.

6. Arie, Kusumaningrum, Hepriyani dan Nurhalinah. Pengaruh PHBS Tatanan Rumah Tangga terhadapa Diare Balita di Kelurahan Gandus Palembang. Jurnal UNSRI. 2011; 132-138.

7. Dini, Fitra, Rizanda Machmud dan Rosial Rasyid. Hubungan Faktor Lingkungan dengan Kejadian Diare Balita di Wilayah Kerja Puskesmas Kambang Kecamatan Lengayang Kabupaten Pesisir Selatan Tahun 2013. Jurnal Kesehatan Andalas. 2015; 4(2).

8. Puskesmas Kodingareng Lompo. Data Penya- kit BL 1. Makassar: Puskesmas Kodingareng; 2015.

9. A, Basyarat. Kajian terhadap Penetapan Lokasi TPA Sampah Leuwinanggung Kota Depok [Thesis]. Semarang: Universitas Diponegoro; 2006.

10. A, Miswar. Penentuan Lokasi Tempat Pembuangan Akhir (TPA) Sampah Kota Banjarbaru Menggunakan Sistem Informasi Geografis (SIG). Jurnal Enviro Scienteae.2001; 8(1): 1622.

11. Setiawan, F. Aplikasi Penginderaan Jauh dan GIS untuk Penentuan Lokasi TPA Sampah di Kota Surabaya. Seminar Nasional Aplikasi Teknologi Informasi; 2010 (SNATI 2010).

12. Miswar, A. Penentuan Lokasi Tempat Pembuangan Akhir (TPA) Sampah Kota Banjarbaru Menggunakan Sistem Informasi Geografis (SIG). Jurnal Enviro Scienteae. 2012;8(1):1622.

13. Permen No 33 Tahun 2010. Pedoman Pengelolaan Sampah. Jakarta: Kementerian Dalam Negeri.

14. I, F, Tobing. Dampak Sampah terhadap Kesehatan Lingkungan dan Manusia. Makalah Loka Karya Aspek Lingkungan dan Legalitas Pembuangan Sampah serta Sosialisasi Pemanfaatan Sampah Organik sebagai Bahan Baku Pembuatan Kompos" Kerjasama Univ Nasional dan Dikmenti DKI; Juni 2005; Jakarta. Jakarta: Fakultas Biologi Universitas Nasional; 2005.

15. Irawan, B A, dan Andi Renata AY. Studi Kelayakan Penentuan Tempat Pemrosesan Akhir Sampah (TPA) di Pulau Bintan Provinsi Kepulauan Riau. Jurnal Ilmu Lingkungan. 2014; 12 (1):1-11. ISSN : 1829-8907

16. Darnas, Yeggi. Studi Kelayakan Lokasi Tempat Pemrosesan Akhir (Tpa) Sampah Kabupaten Padang Pariaman. Seminar Nasional Sains dan Tek. Lingkungan II. 2016; e-ISSN 2541-3880.

17. Budiman. Ilmu Kesehatan Masyarakat Dalam Konteks Kesehatan Lingkungan. Jakarta: EGC; 2010. 